\title{
Effect of Environmental Sustainability Cost on the Financial Position of Quoted Manufacturing Firms in Nigeria: Evidence from Healthcare Sector
}

\author{
Ubesie Madubuko Cyril Ugwueze, Catherine Amaka, Nwachukwu Basilia Chiamaka \\ Department of Accountancy, Faculty of Management Sciences, Enugu State University of Science and Technology, Enugu, Nigeria \\ Email address: \\ ubesiemadubuko@yahoo.com (U. M. C. Ugwueze)

\section{To cite this article:} \\ Ubesie Madubuko Cyril Ugwueze, Catherine Amaka, Nwachukwu Basilia Chiamaka. Effect of Environmental Sustainability Cost on the \\ Financial Position of Quoted Manufacturing Firms in Nigeria: Evidence from Healthcare Sector. Journal of Business and Economic \\ Development. Vol. 6, No. 3, 2021, pp. 184-195. doi: 10.11648/j.jbed.20210603.18
}

Received: July 15, 2021; Accepted: August 3, 2021; Published: September 30, 2021

\begin{abstract}
This study empirically explored the effect of environmental sustainability cost on the financial position of quoted manufacturing firms in Nigeria with evidence from the healthcare sector. In achieving the research target, the study estimated the effect of community development cost, employee benefit cost and raw material cost on the profit after tax of the selected healthcare manufacturing sector. Research design adopted was ex-post facto design while analytical tools employed were descriptive statistics and vector auto regression analysis techniques. Relevant diagnostic tests such as panel unit root (stationarity) test and co-integration test. Findings revealed that environmental sustainability cost operationalized by community development cost, employee benefit cost and raw material cost contributes positively to the long-run sustainable growth and development of healthcare manufacturing firms in Nigeria. On this background, the study suggested that healthcare manufacturing firms in Nigeria should consider investing in their workers through engaging them in various educational training and other beneficial skills for improved performance and organizational productivity. The firms should equally consider investment in community development projects of their host communities since they lead to more patronage which makes the company to thrive.
\end{abstract}

Keywords: Profit After Tax, Community Development Cost, Employee Benefit Cost, Raw Material Cost

\section{Introduction}

\subsection{Background to the Study}

Some business activities generate pollution and waste that can damage natural systems, causing irreversible harms, which reduce environmental resources available to society. Effective and sustainable healthcare system is the key to providing quality healthcare at a low cost, with large population coverage and effective disease management [1]. The pursuit for sustainability and the preservation of existing resources mandates that organizations must develop new ways and attitudes of doing business in terms of environmental sustainability. However, environmental sustainability has become a pressing issue across the globe [2].

Environmental costs are incurred in preventing, reducing or repairing damage to the environment and conserving resources such as cleanup costs, costs of recycling materials or conserving energy, closure costs, capital expenditure and development expenditure. Environmental costs cover all costs incurred concerning environmental protection such as emissions treatment as well as wasted material, capital and labour which are called 'non-product output' as a result of their inefficiency in production activities [3]. They also include fines, penalties, compensation, and disposal losses relating to assets which have to be scrapped or abandoned because they damage the environment $[4,5]$.

Nowadays, firms generate a lot of environmental problems in struggling for: profit maximization, satisfying the endless needs, to update with the rapidly advancing technological developments, and unconscious consumption of natural resources. Hence, they must take care of preventing and reducing their environmental impact through corporate environmental practices, which also have an impact on firms' financial performance [6]. Efforts to reduce this environmental pollution are additional cost to the companies 
in the short-term. Nevertheless, according to [7], they can have a chance of cost minimization in medium and long-term and even additional income in this process.

Presently, due to intense competition in healthcare sector, they are faced with multiple challenges to cope with the current healthcare needs, including sustainability as one of the essential requirements to obtain strategic fit for the future. In view of this, developing an effective sustainable healthcare system has become a difficult task. This study however set out to investigate the effect of environmental sustainability cost on the financial position of quoted manufacturing firms in Nigeria with evidence from the healthcare sector.

\subsection{Statement of the Problem}

The Nigerian environment had continued to pose significant challenge to business growth within. Sustaining the environment in the form of ensuring that costs incurred in aspects of employee benefit, raw materials, and community development are matched with the financial position of the firm had remained an issue of controversy. Particularly, failure of the firms to integrate environmental sustainability cost into the business operation had grossly influenced the firm's financial performance (positively and negatively). In order to bounce back, the firms must take a due consideration of critical examination of both the magnitude and direction of effect of these costs on the business growth, and also work towards adopting environmental and social policies capable of destroying the shareholder's wealth and values. There is also the need to ensure that the companies do not experience higher cost structure which may result to them being eliminated by their competitors. This study however, set forth to ascertain the effect of employee benefit cost, raw material cost, and community development cost on the financial position of healthcare manufacturing sector in Nigeria.

\subsection{Objectives of the Study}

The main objective of this study is to ascertain the effect of environmental sustainability cost on the financial position of quoted manufacturing firms in Nigeria, with evidence from healthcare sector. The specific objectives were to:

Ascertain the effect of community development cost on profit after tax of healthcare manufacturing sector in Nigeria.

Determine the effect of employee benefit cost on profit after tax of healthcare manufacturing sector in Nigeria.

Find out the effect of raw material cost on profit after tax of healthcare manufacturing sector in Nigeria.

\subsection{Statement of Hypotheses}

Community development cost has no significant effect on profit after tax of healthcare manufacturing sector in Nigeria.

Employee benefit cost has no significant effect on profit after tax of healthcare manufacturing sector in Nigeria.

Raw material cost has no significant effect on profit after tax of healthcare manufacturing sector in Nigeria.

\section{Review of Related Studies}

The study is underpinned by the Stakeholder's theory. The
Stakeholder theory was propounded by Edward R. Freeman in 1984. Stakeholder theory views corporations as part of a social system while focusing on the various stakeholder groups within society. They comprise of individuals and constituencies that contribute voluntarily and involuntarily to the firms' wealth and activities that lead them as the potential beneficiaries [8]. Stakeholders are shareholders, employees, suppliers, consumers, government, media, creditors, interest groups, and general public. Stakeholders are identified by companies to ascertain which groups need to be managed in order to further the interest of the corporation.

In general, stakeholder theory is prioritizing the relationship between an organization and its stakeholders. This is because the central idea of the theory is to attain success which depends on the capability of the company to sustain her relationship with the stakeholder groups, such as employees, customers, and even general public [9]. Stakeholder's theory explains specific corporate actions and activities using a stakeholder-agency approach, and it is concerned with how relationships with stakeholders are managed by companies in terms of the acknowledgement of the society where they operate.

\section{Empirical Studies}

Essentially, several empirical literatures abound on the study of environmental sustainability cost and financial position of manufacturing firms. These literatures differ in terms of time, space, setting and methodology. Etale and Otuya (2018) employed ordinary least square (OLS) regression method to examine the relationship between environmental responsibility reporting and financial performance of quoted oil and gas companies in Nigeria [10]. The study used secondary data obtained from the annual reports of 13 oil and gas companies quoted on the floor of the Nigeria Stock Exchange (NSE) for the period of 2012-2017. The result showed a significant positive relationship between financial performance and environmental responsibility reporting in the oil and gas sector of Nigeria. Also, provided by the study was that environmental responsibility reporting in Nigeria was still developing and that organizations operating in the oil and gas sector report very little information about the impact of their operations on the environment.

Karamat et al (2019) used structural equation modeling to examine the role of barriers, enablers and drivers on Knowledge Management (KM) adoption in Pakistan [1]. The finding revealed that organizational and strategic barriers have significant negative association with $\mathrm{KM}$ adoption; government related enablers have significant positive association with KM adoption; healthcare related drivers, and performance-based drivers have significant positive association with KM adoption.

Using Correlation coefficient, the coefficient of determination and the simple regression analysis model, Akparhuere (2019) examined the effectiveness of environment reporting in annual reports using a comparative analysis of reporting practices of listed firms in Nigeria [11]. The finding showed that discretionary social responsibility 
reporting practices (donations and gifts) have significant effects on performance of both oil and gas firms and consumer goods companies in Nigeria.

Obara, Ohaka and Nangih (2017) used simple regression analysis technique to examine the effect of accounting for waste management expenditure on the profitability of oil and gas companies in Nigeria [12]. The finding showed that waste management has high positive and significant influence on the Return on Assets, Return on Equity and Operating Profit Level of the oil and gas companies in Nigeria.

Nyirenda, Ngwakwe and Ambe (2013) examined the impact of environmental management practices on financial performance in South Africa using a Johannesburg Stock Exchange listed mining company as case study [13]. Return on equity proxy for financial performance was regressed against elements of environmental management practices such as carbon reduction, energy efficiency, and water usage. Multiple regression statistics was used as methods of data analysis. The result showed no significant relationship between environmental management practices and financial performance.

Nnamani, Onyekwelu and Ugwu (2017) investigated the effect of sustainability accounting on financial performance and used the ordinary linear regression tools for the analysis of secondary data collected from 3 listed brewery companies in Nigeria for the period 2010 to 2014 [14]. The study found that sustainability accounting had significant positive effect on financial performance of brewery companies in Nigeria.

Owolabi, Taleatu, Adetula and Uwaigbe (2016) examined the extent of sustainability reporting by Lafarge Africa Plc [15]. Data sourced from the 2014 annual report of the company were examined through content analysis using the Global Reporting Initiative (GRI) guidelines as basis of assessment. The study revealed low sustainability reporting practice by the company (that is, no disclosures on human right issues, 3\% environmental disclosures, and $30 \%$ disclosure based on 169 indicators). They recommended the need for regulation of sustainability reporting practices among firms in the country.

Ofoegbu, Odoemelam and Okafor (2018) used descriptive statistics, correlation analysis and multiple regression model to examine the influence of corporate board characteristics and environmental disclosure quantity of listed firms in two leading emerging economies in South Africa and Nigeria [16]. The result showed that environmental disclosures are more relevant in the South African sample and less in Nigeria sample. Furthermore, the board characteristics statistically significantly associated with the extent of environmental disclosure of listed firms in South Africa and Nigeria.

Malarvizhi and Ranjanni (2016) employed regression model to examine whether there was any significant relationship between Corporate Environmental Disclosure (CED) and firm performance of selected companies listed in Bombay Stock Exchange (BSE), India [17]. The finding revealed that there was no significant relationship between the level of environmental disclosure and firm performance.
Menhat and Yusuf (2018) investigated the factors influencing the choice of performance measures for the oil and gas supply chain. An exploratory approach was adopted for this study consisting of in-depth interview with five supply chain practitioners from the oil and gas industry. The finding revealed a significant impact of the influencing factors in the choice of performance measures [18].

Using regression analysis, Alawiye-Adams and Akomolafe (2017) examined the inadequacies of corporate environmental disclosures both in quantity and quality amongst manufacturing firms in Nigeria for a period of six years (2010 to 2015). The finding revealed that corporate environmental disclosure was still at its lowest ebb amongst manufacturing firms in Nigeria and there would be a need for sensitization, regulatory compulsion or government intervention for companies to participate in corporate environmental disclosure [19].

Using unit root and co-integration test of panel data, Kai (2015) examined the effect of environmental performance and preference disclosure on financial performance using evidence from unbalanced panel data of heavy-pollution industries in China [2]. The finding showed that environmental performance has a significant negative impact on Tobin's Q, while environmental propensity has a significant positive effect on Tobin's Q. Furthermore, firm size, financial leverage and return on assets have significant positive impacts on financial performance of the industries. Also, corporate environmental performance and propensity on financial performance has a significant periodic difference from 2008 to 2012.

Zhang and Chen (2017) used regression and panel analysis to investigate the impact of environmental performance and financing decisions on sustainable financial development of Chinese environmental protection enterprises from 2007 to 2016 [20]. The result showed that debt financing has a significant impact on short- and long-term economic performance. Firms prefer long-term debt over short-term debt to improve their financial sustainability. Internal financing is positively related to performance because the cost of financing is lower. Environmental performance can cause extra financial burden in the short run, but will improve stakeholder relations and profitability in the long run.

Odera (2016) examined the quality of social and environmental disclosures by Nigerian oil companies. Correlation analysis, Kolmongrov-Smirnov and ShapiroWilk tests were used to analyze the data collected. Result showed that SED activities are reported by most of the companies, and by quantity, employee information to be the most common type of disclosure [21]. Also, SED quantity and quality in the environment category was found to be overwhelmingly low despite the large-scale public concern expressed about the levels of the environmental degradation caused by oil company operations.

Osazefua (2019) investigated the impact of operational efficiency on the financial sustainability of listed manufacturing companies in Nigeria. A secondary panel dataset ranging from 2009 to 2016 for 16 listed 
manufacturing companies was obtained from the Bloomberg portal and analysed using Ordinary Least Square method. The finding revealed that in relation to ROA, operating expenses and asset turnover had negative and positive significant relationship respectively. Employees' growth, account receivables, turnover, and inventory turnover was found to be insignificant. In relation to Tobin's q, both inventory and asset turnover had a positive significant relationship. Operating expense had a negative significant relationship [22].

Dibia and Onwuchekwa (2015) used binary regression technique to examine the determinants of environmental disclosures using oil and gas companies in Nigeria. The finding revealed that there is a significant relationship between company size and corporate social responsibility disclosures. Also, there is no significant relationship between Profit, Leverage, Audit firm type and corporate social responsibility disclosures [23].

Okegbe and Ofurum (2019) empirically examined the effect of environmental management accounting and financial performance of Nigerian consumer goods firms. The study employed ordinary least square regression estimation technique and found that environmental restoration cost, pollution prevention cost and environmental protection cost have effect on return on assets of quoted Nigerian consumer goods firms [24].

Shehu (2014) employed the multiple regression analysis technique to investigate the effect of environmental expenditure on the performance of quoted Nigerian oil companies, for the period of twelve years (1999-2010). Empirical evidence from the study exposed that environmental expenditure has significant effect on the performance of quoted oil companies in Nigeria [25].

Panel Corrected Standard Error Regression analysis was employed by Mohammed (2018) to examine the mandatory social and environmental disclosure using performance evaluation of listed Nigerian oil and gas companies pre- and post-mandatory disclosure requirements. The result showed $53 \%$ increase in volume of social disclosure and $235 \%$ increase in volume of environmental disclosure six years post-code over disclosure six years pre-code. Also, the mean of disclosure six years post code was greater than the mean of disclosure six years pre- code and corporate size, has positive and significant relationship with disclosure [26].

Ndubuisi-Okolo, Anekwe and Attah (2016) employed Pearson Product Moment Correlation (PPMC) coefficient and one-sample Kolmogorov-Smirnov (K-S) test to investigate waste management and sustainable development in Nigeria with particular reference to Anambra State Waste Management Agency (ASWAMA). The finding revealed that waste management practice has a significant relationship with environmental sustainability in Anambra State [27].

Using Pearson correlation and multiple linear regression analysis technique, Nwaiwu and Oluka (2018) examined the effect of environmental cost disclosure and financial performance measures of quoted oil and gas companies in Nigeria. The finding showed that adequate disclosure on environmental cost, compliance to corporate environmental regulations have positive significant effect on financial performance measures [28].

Nazaripour and Shadi (2015) investigated the impact of financing on evaluating the performance of companies listed on the Stock Exchange in Tehran through debt and the optimal structure of debt during years 2010 to 2013. Multivariate regression analysis, based on the method of combined data was used for testing hypotheses. The result showed that there is a negative and significant relationship between financing through debt and performance. Also, there is a positive and significant relationship between the optimal structure of debt and the performance of the company, and difference of the average of efficiency, between optimal and non-optimal structure of debt is 0.182 and meaningful [29].

Agbo, Ohaegbu and Akubuilo (2017) examined the effect of environmental cost on financial performance of Nigerian brewery using multiple regression analysis. The finding showed that both donation and medical expenses have a negative relationship respectively with return on assets (ROA). Trainings, Recruitment and Canteen Expenses (TRC) and the return on assets (ROA) have a positive relationship on Nigerian brewery Plc [30].

Multiple regression technique was employed by Abubakar (2017) to examine the influence of firm attributes on environmental disclosure of listed breweries companies in Nigeria from 2012 to 2016 . The finding showed that board size has negative but significant influence on environmental disclosure; leverage has negative and insignificant influence on environmental disclosure; while firm size has positive and insignificant influence on environmental disclosure of the listed breweries companies in Nigeria [31].

Using Regression Analysis, Ezejiofor, John-Akamelu, and Chigbo (2016) examined the effect of sustainability accounting measure on the performance of corporate organizations in Nigeria using data from annual reports and accounts of the company in Nigeria. The finding showed that environmental cost impacts negatively on revenue, while positively on profit generation of corporate organizations in Nigeria [5].

\section{Methodology}

The study adoptedex-post facto research design. Data for the study was annual time series secondary data obtained from the annual accounts and financial statements of the selected healthcare manufacturing firms in Nigeria from 2009 - 2018. Panel unit root test was performed on the data series to establish the stationarity state of the dataset. The essence of the stationarity test was also to know if the data were spurious.

Also, before empirical estimation, the secondary data were subjected to descriptive analysis considering the mean, standard deviation, skewness, kurtosis, and Jarque-Bera goodness of fit test. The reason was to ascertain the behaviour of the dataset and provide estimate of the spread out from the central mean, estimate extent of their symmetry 
and tail thickness for the period of study which by extension informs whether parametric or non-parametric tools are appropriate for further estimation.

The Jarque and Bera (1987) test of normality was given by:

$$
\mathrm{JB}=\frac{\hat{S}^{2}(x)}{6 / T}+\frac{(\widehat{K}(x)-3)^{2}}{24 / T}
$$

Where,

$x$ represents the parameter of interest

$\hat{S}_{(x)}$ and $\widehat{K}_{(x)}$ are estimates of the skewness and kurtosis respectively.

The skewness $\left(S_{(x)}\right) \sim \mathrm{N}\left(0, \frac{6}{T}\right)$ while the kurtosis $\left(K_{(x)}\right) \sim$ $\mathrm{N}\left(0, \frac{24}{T}\right)$. This implies that the skewness and kurtosis estimates are assumed to be normally distributed with zero mean and variances $\frac{6}{T}$ and $\frac{24}{T}$ respectively; $\mathrm{t}$ is the time period.

The J-B statistic is asymptotically distributed as Chisquared random variable with 2-degrees of freedom. In this test, the null hypothesis (Ho) of normality is rejected if the pvalue of $\mathrm{J}-\mathrm{B}$ statistic is less than the specified significance level; otherwise Ho is upheld.

Inferentially, the study employed the vector autoregression
(VAR) analysis mechanism. The VAR model is an extension of univariateautoregression model to multivariate time series data. The choice of this technique was appropriate as study variables are stationary at first differencing and were thus not cointegrated.

The general model for vector autoregression of order $p$ $(\operatorname{VAR}(\mathrm{p}))$ was given by:

$$
Y_{t}=\alpha+\beta_{1} Y_{t-1}+\beta_{2} Y_{t-2}+\cdots+\beta_{p} Y_{t-p}+C X_{t}+\mu_{t}
$$

Where,

$Y_{t}=y_{1 t}, y_{2 t}, \ldots, y_{n t}:$ an $(\mathrm{n} \times 1)$ vector of dependent variables,

$X_{t}=x_{1 t}, x_{2 t}, \ldots, x_{n t}:$ an $(\mathrm{n} \times 1)$ vector of independent variables,

$\alpha=$ an $(\mathrm{n} \times 1)$ vector of intercepts,

$\beta_{i}(i=1,2, \ldots, \mathrm{p})$ : an $(\mathrm{n} \times 1)$ vector of lag coefficients of the dependent variable,

$\mu_{t}=$ an $(\mathrm{n} \times 1)$ vector of unobservable independent and identically distributed (i.i.d) zero mean error term (white noise).

Explicitly for this study, we have that:

$$
\begin{aligned}
\Delta \operatorname{Ln}\left(P A T_{t}\right) & =\alpha+\sum_{i=1}^{a} \beta_{i} \Delta \ln (P A T)_{t-i}+\sum_{t=1}^{b} \beta_{i} \Delta \ln (E B C)_{t-i}+\sum_{t=1}^{c} \beta_{i} \Delta \ln (R M C)_{t-i}+\sum_{t-1}^{d} \beta_{i} \Delta \operatorname{Ln}(C D C)_{t-i}+\mu_{1 t}(3) \\
\Delta \operatorname{Ln}\left(E B C_{t}\right) & =\alpha+\sum_{i=1}^{b} \beta_{i} \Delta \ln (E B C)_{t-i}+\sum_{t=1}^{a} \beta_{i} \Delta \ln (P A T)_{t-i}+\sum_{t=1}^{c} \beta_{i} \Delta \ln (R M C)_{t-i}+\sum_{t-1}^{d} \beta_{i} \Delta \operatorname{Ln}(C D C)_{t-i}+\mu_{2 t}(4) \\
\Delta \operatorname{Ln}\left(R M C_{t}\right) & =\alpha+\sum_{i=1}^{c} \beta_{i} \Delta \ln (R M C)_{t-i}+\sum_{t=1}^{a} \beta_{i} \Delta \ln (P A T)_{t-i}+\sum_{t=1}^{b} \beta_{i} \Delta \ln (E B C)_{t-i}+\sum_{t-1}^{d} \beta_{i} \Delta \operatorname{Ln}(C D C)_{t-i}+\mu_{3 t}(5) \\
\Delta \operatorname{Ln}\left(C D C_{t}\right) & =\alpha+\sum_{i=1}^{d} \beta_{i} \Delta \ln (C D C)_{t-i}+\sum_{t=1}^{a} \beta_{i} \Delta \ln (P A T)_{t-i}+\sum_{t=1}^{b} \beta_{i} \Delta \ln (E B C)_{t-i}+\sum_{t-1}^{c} \beta_{i} \Delta \operatorname{Ln}(R M C)_{t-i}+\mu_{4 t}(6)
\end{aligned}
$$

Where,

$\Delta$ Stands for difference operator,

$\mathrm{Ln}$ is the log-transformational operator

The lag length (t-1) are determined automatically by the modified AIC and are represented by a, b, c, and d. $\sigma$ is the constant, $\operatorname{Ln}(P A T)_{t}=\log$-transformed value of Profit after Tax. It is a vector such that $\operatorname{Ln}(P A T)_{t}$ for the five firms is:

$$
\operatorname{Ln}(P A T)_{t}=\left[\operatorname{Ln}(P A T)_{t, 1} \operatorname{Ln}(P A T)_{t, 2} \operatorname{Ln}(P A T)_{t, 3} \quad \operatorname{Ln}(P A T)_{t, 4} \quad \operatorname{Ln}(P A T)_{t, 5}\right]
$$

$\operatorname{Ln}(C D C)_{t}=$ Log-transformed value of Community Development Cost. It is a vector such that $\operatorname{Ln}(C D C)_{t}$ for the five firms is:

$$
\operatorname{Ln}(C D C)_{t}=\left[\operatorname{Ln}(C D C)_{t, 1} \operatorname{Ln}(C D C)_{t, 2} \operatorname{Ln}(C D C)_{t, 3} \operatorname{Ln}(C D C)_{t, 4} \operatorname{Ln}(C D C)_{t, 5}\right]
$$

$\operatorname{Ln}(E B C)_{t}=$ Log-transformed value of Employee Benefit Cost. It is a vector such that $\operatorname{Ln}(E B C)_{t}$ for the five firms is:

$$
\operatorname{Ln}(E B C)_{t}=\left[\operatorname{Ln}(E B C)_{t, 1} \operatorname{Ln}(E B C)_{t, 2} \operatorname{Ln}(E B C)_{t, 3} \operatorname{Ln}(E B C)_{t, 4} \operatorname{Ln}(E B C)_{t, 5}\right]
$$

$\operatorname{Ln}(R M C)_{t}=$ Log-transformed value of Raw Material Cost. It is a vector such that $\operatorname{Ln}(R M C)_{t}$ for the five firms is:

$$
\operatorname{Ln}(R M C)_{t}=\left[\operatorname{Ln}(R M C)_{t, 1} \operatorname{Ln}(R M C)_{t, 2} \operatorname{Ln}(R M C)_{t, 3} \operatorname{Ln}(R M C)_{t, 4} \operatorname{Ln}(R M C)_{t, 5}\right]
$$

$\beta_{0}$ is a vector such that: $\beta_{0}=\left[\beta_{0,1} \beta_{0,2} \beta_{0,3} \beta_{0,4} \beta_{0,5}\right] ; \beta_{1}$ is a vector such that: $\beta_{1}=\left[\beta_{1,1} \beta_{1,2} \beta_{1,3} \beta_{1,4} \beta_{1,5}\right]$;

$\beta_{2}$ is a vector such that: $\beta_{2}=\left[\beta_{2,1} \beta_{2,2} \beta_{2,3} \beta_{2,4} \beta_{2,5}\right]$; and $\beta_{3}$ is a vector such that: $\beta_{3}=\left[\beta_{3,1} \beta_{3,2} \beta_{3,3} \beta_{3,4} \beta_{3,5}\right]$; and

$\varepsilon_{t}$ is a vector such that: $\varepsilon_{t}=\left[\varepsilon_{t, 1} \varepsilon_{t, 2} \varepsilon_{t, 3} \varepsilon_{t, 4} \varepsilon_{t, 5}\right]$;

$\beta_{1}-\beta_{4}$ are the long run multipliers, $\beta_{0}$ is the drift while $u_{t}$ is the white noise time invariant error.

The lag length of the model will be determined following the Schwartz Information Criterion with the optimal lag length being the lag with the least information criterion.

Cointegrating relationship amongst the variables wastested following the panel data cointegration test procedure. Decision was taken at 0.05 level of significance. Should a cointegration exist, error correction analysis is performed. The estimates were subjected to diagnostic tests to confirm their validity and as well reliability.

Durbin-Watson (DW) Statistic: This statistic was used to 
test for first order serial correlation in the errors of a regression model under the classical linear model assumptions (Wooldridge, 2009). It assists in specifying the right combination of the explanatory variables.

Description of Model Variables

Profit after-Tax: Profit after-tax is the earnings of a business after all income taxes have been deducted. It is the net amount earned by a business after all taxation related expenses have been deducted. It is used as an indicator to determine how much a business really earns and to measure a company's profitability after when all its expenses have been deducted.

Community Development Cost: These include capital costs in form of donation or gift by the organization to the community for their economic, social, environmental and cultural wellbeing.

Employee Benefit Cost: Employee benefits are any kind of compensation provided in a form other than direct wages and paid for in whole or in part by an employer, even those provided by a third party (e.g., government). Employees receive these benefits above and beyond their wages. The range of employee benefits includes educational, employee incentive, family, government, health, lifestyle, recreational, retirement, savings, and transportation benefits. While some benefits such as government sanctioned ones are mandatory, others are supplementary or optional at the discretion of employers. Unlike wages alone, benefits foster economic security and stability by insuring beneficiaries against uncertain events such as unemployment, illness, and injury. In doing so, organizations improve their worker retention.

Raw Material Cost: Raw materials are the inputs or resources that a company uses to manufacture its finished products to sell to consumers. They include goods that require further processing as well as finished goods used in their received form. However, the raw material costs refer to the cost of the drugs components that go into a final manufactured product.

\section{Data Analysis and Interpretation of Results}

Analysis of the research data were presented in two segments: descriptive and inferential statistics. The descriptive statistics result is as presented in table 1 below:

Table 1. Descriptive Statistics and Normality Test.

\begin{tabular}{|c|c|c|c|c|}
\hline Parameters & PAT & EBC & RMC & CDC \\
\hline Mean & 453939.1 & 187677.4 & 479424.0 & 6378737. \\
\hline Median & 169507.5 & 96467.00 & 306557.5 & 926085.0 \\
\hline Maximum & 2919170. & 900138.0 & 1980569. & 40486309 \\
\hline Minimum & -464094.0 & -108940.0 & 32945.00 & 39810.00 \\
\hline Std. Dev. & 834996.3 & 198046.3 & 479077.8 & 11998967 \\
\hline Skewness & 1.570087 & 1.785735 & 1.542795 & 1.854122 \\
\hline Kurtosis & 4.704264 & 5.783272 & 5.006085 & 4.816009 \\
\hline Probability & 0.000002 & 0.000000 & 0.000001 & 0.000000 \\
\hline Sum & 22696955 & 9383869. & 23971199 & $3.19 \mathrm{E}+08$ \\
\hline Sum Sq. Dev. & $3.42 \mathrm{E}+13$ & $1.92 \mathrm{E}+12$ & $1.12 \mathrm{E}+13$ & $7.05 E+15$ \\
\hline Observations & 50 & 50 & 50 & 50 \\
\hline
\end{tabular}

Source: Author's E-views 10 result

The descriptive statistics shows estimates of the mean, standard deviations, skewness, kurtosis, and Jarque-Bera statistics of the study variables. The result shows that all the variables are skewed to the right and are platykurtic. The standard deviations of the variables are volatile and therefore of low predictive power. The Jarque-Bera statistics and associated probability values less than 0.05 (i.e., $p<0.05$ ) indicates that the distribution of the variables are not normal. However, the Levin, Lin \& Chu t* panel unit root test was performed to ascertain the stationarity state of the series.

Table 2. Unit Root and Cointegration Test Result.

\begin{tabular}{lllll}
\hline Variable & Levin, Lin,\& Chu t* statistic & p-value & Order of integration & Inference \\
\hline LnPAT & -7.13 & 0.0000 & $\mathrm{I}(1)$ & Stationary \\
LnCDC & -5.08 & 0.0000 & $\mathrm{I}(1)$ & Stationary \\
LnEBC & -10.16 & 0.0000 & $\mathrm{I}(1)$ & Stationary \\
LnRMC & -4.99 & 0.0000 & $\mathrm{I}(1)$ & Stationary \\
\hline
\end{tabular}

Pedroni Residual Cointegration

Panel rho-Statistic (Prob.) $=-0.902$ (0.8165)

Source: Author's computation using Eviews 10

The panel unit root test (Levin, Lin \& Chu t* method) with p-values $<0.05$ shows that the variables are stationary at first differencing; hence, the null hypothesis of panel unit root in the variables were rejected at first differencing, indicating the variables are integrated of order one.

The Pedroni Residual cointegration with panel rho statistic value of -0.902 and associated probability value of $0.8165>0.05$ shows that the variables are free from 
cointegration problem. For which course, the VAR estimate is as presented below:

Table 3. Vector Autoregression Estimates.

\begin{tabular}{|c|c|c|c|c|}
\hline & LNPAT & LNEBC & LNRMC & LNCDC \\
\hline \multirow[t]{3}{*}{ LNPAT (-1) } & 0.207652 & 1.098287 & 0.150909 & 0.407116 \\
\hline & $(0.53569)$ & $(0.85734)$ & $(0.58682)$ & $(0.60647)$ \\
\hline & {$[0.38764]$} & [1.28104] & {$[0.25716]$} & {$[0.67128]$} \\
\hline \multirow[t]{3}{*}{ LNPAT (-2) } & 0.413487 & 1.062829 & 0.285383 & -0.456230 \\
\hline & $(0.67731)$ & $(1.08400)$ & $(0.74196)$ & $(0.76681)$ \\
\hline & {$[0.61048]$} & [0.98047] & [0.38463] & {$[-0.59497]$} \\
\hline \multirow[t]{3}{*}{$\operatorname{LNEBC}(-1)$} & -0.724468 & 0.228413 & -0.798563 & -0.727911 \\
\hline & $(0.40335)$ & $(0.64554)$ & $(0.44185)$ & $(0.45665)$ \\
\hline & {$[-1.79613]$} & {$[0.35383]$} & {$[-1.80731]$} & {$[-1.59402]$} \\
\hline \multirow[t]{3}{*}{ LNEBC (-2) } & 0.563781 & 0.539622 & 0.751412 & 0.784847 \\
\hline & $(0.33190)$ & $(0.53118)$ & $(0.36358)$ & $(0.37575)$ \\
\hline & [1.69867] & [1.01589] & {$[2.06672]$} & [2.08872] \\
\hline \multirow[t]{3}{*}{$\operatorname{LNRMC~(-1)~}$} & 1.544206 & 0.992468 & 1.294030 & 1.385973 \\
\hline & $(0.49587)$ & $(0.79361)$ & $(0.54320)$ & $(0.56139)$ \\
\hline & [3.11416] & {$[1.25058]$} & [2.38224] & [2.46882] \\
\hline \multirow[t]{3}{*}{ LNRMC (-2) } & -1.120128 & -3.123381 & -0.838735 & -1.470670 \\
\hline & $(0.81509)$ & $(1.30451)$ & $(0.89290)$ & $(0.92280)$ \\
\hline & {$[-1.37423]$} & {$[-2.39429]$} & {$[-0.93934]$} & {$[-1.59370]$} \\
\hline \multirow[t]{3}{*}{$\operatorname{LNCDC}(-1)$} & -0.322600 & -1.446904 & -0.037752 & -0.351805 \\
\hline & $(0.47544)$ & $(0.76092)$ & $(0.52083)$ & $(0.53827)$ \\
\hline & {$[-0.67853]$} & {$[-1.90151]$} & {$[-0.07249]$} & {$[-0.65358]$} \\
\hline \multirow[t]{3}{*}{$\operatorname{LNCDC}(-2)$} & 0.322428 & 1.698444 & 0.110725 & 1.431483 \\
\hline & $(0.50824)$ & $(0.81341)$ & $(0.55675)$ & $(0.57540)$ \\
\hline & {$[0.63440]$} & [2.08806] & [0.19888] & [2.48782] \\
\hline \multirow[t]{3}{*}{$\mathrm{C}$} & 1.356955 & -2.181045 & 0.653680 & -0.091937 \\
\hline & $(3.93968)$ & $(6.30525)$ & $(4.31573)$ & $(4.46028)$ \\
\hline & {$[0.34443]$} & {$[-0.34591]$} & {$[0.15146]$} & {$[-0.02061]$} \\
\hline R-squared & 0.957390 & 0.818989 & 0.941572 & 0.979954 \\
\hline Adj. R-squared & 0.889215 & 0.529373 & 0.848088 & 0.947879 \\
\hline Sum sq. resids & 0.802865 & 2.056486 & 0.963453 & 1.029071 \\
\hline S. E. equation & 0.400716 & 0.641325 & 0.438965 & 0.453668 \\
\hline F-statistic & 14.04307 & 2.827837 & 10.07196 & 30.55255 \\
\hline Log likelihood & 0.145243 & -6.438729 & -1.131118 & -1.592335 \\
\hline Akaike AIC & 1.264965 & 2.205533 & 1.447303 & 1.513191 \\
\hline Schwarz SC & 1.675788 & 2.616355 & 1.858125 & 1.924013 \\
\hline Mean dependent & 13.41949 & 12.32688 & 13.07714 & 14.51826 \\
\hline S. D. dependent & 1.203915 & 0.934844 & 1.126247 & 1.987156 \\
\hline Determinant resid covariance (dof adj.) & & 0.000321 & & \\
\hline Determinant resid covariance & & 5.23E-06 & & \\
\hline Log likelihood & & 5.673082 & & \\
\hline Akaike information criterion & & 4.332417 & & \\
\hline Schwarz criterion & & 5.975707 & & \\
\hline Number of coefficients & & 36 & & \\
\hline
\end{tabular}

Source: Author's computation using Eviews 10

As shown in the result above, the Vector Autoregression (VAR) estimates of the dynamic effect of environmental sustainability cost on the financial position of quoted healthcare manufacturing firms in Nigeria showed that employee benefit cost (LnEBC) and community development cost ( $\mathrm{LnCDC}$ ) have short-run negative and long-run positive but insignificant effects on profit after tax (LnPAT) of the selected quoted healthcare firms; while raw material cost (LnRMC) has short-run positive and long-run negative butinsignificant effect on LnPAT of the selected firms in Nigeria.

The R-squared estimate which measures overall effect of the explanatory variables on the response variable is 0.957 . This indicates that the model is a good one as about $95.7 \%$ of the total variations in LnPAT of the healthcare firms in
Nigeria can be explained by the selected environmental sustainability costs. The F-statistic value of 14.043 is high indicating a joint significant effect of the independent variables on the dependent variable.

Irrespective of the variations in analytical methods and scope, the finding of this study affirms with some earlier related works in Nigeria and developed countries. Specifically, our finding identifies with the finding of Shehu (2014), Nnamani, et al (2017), Etale and Otuya (2018), Akparhuere (2019), Okegbe and Ofurum (2019), among others $[10,11,14,24,25]$. On the other hand, the finding contradicts the findings of Nyirenda, et al (2013), and Malarvizhi and Ranjanni (2016) [13, 17]. 


\section{Summary, Conclusion and Recommendations}

\subsection{Summary of Findings}

Having empirically investigated the effect of environmental sustainability cost (proxy by employee benefit cost, raw material cost, and community development cost) on the financial position (measured by profit after tax) of quoted healthcare manufacturing firms in Nigeria, the findings emerged that:

Employee benefit cost has short-run negative and long-run positive but insignificant effect on profit after tax of healthcare manufacturing firms in Nigeria.

Raw material cost has short-run positive and long-run negative but insignificant effect on profit after tax of healthcare manufacturing firms in Nigeria.

Community development cost has short-run negative and long-run positive but insignificant effect on profit after tax of healthcare manufacturing firms in Nigeria.

\subsection{Conclusion and Recommendations}

This study empirically investigated the effect of environmental sustainability cost on the financial position of quoted healthcare manufacturing firms in Nigeria. The period covered was ten (10) years: 2009-2018. Using the Vector Autoregression (VAR) mechanism, the study established that environmental sustainability cost affects the financial depth of healthcare manufacturing firms in Nigeria. With respect to the findings, the study made the following recommendations:

Healthcare manufacturing firms in Nigeria should not be discouraged by the environmental costs associated with their business operations; instead, they should invest more on them especially those beneficial to their employees and host community since they contribute to sustainable growth and development firm.

Cost of raw materials should be monitored and various strategies for avoiding high costs of these products should be adopted.

There is also the need for regulation of sustainability reporting practices among Healthcare manufacturing sector in Nigeria.

\section{Appendix}

Table 4. Data Used.

\begin{tabular}{|c|c|c|c|c|c|}
\hline COMPANY & YEARS & PAT & EBC & RMC & CDC \\
\hline FIDSON & 2009 & 429,073 & 450,906 & 259,960 & $18,124,500$ \\
\hline FIDSON & 2010 & 465,893 & 612,365 & 258,853 & $20,098,920$ \\
\hline FIDSON & 2011 & 312,257 & 900,138 & 301,507 & $30,884,922$ \\
\hline FIDSON & 2012 & 206,889 & 622,343 & 192,704 & $11,064,900$ \\
\hline FIDSON & 2013 & 154,980 & 682,389 & 192,002 & $39,420,180$ \\
\hline FIDSON & 2014 & 631,825 & $-108,940$ & 377,531 & $32,877,400$ \\
\hline FIDSON & 2015 & 744,378 & 57,322 & 284,837 & $26,384,483$ \\
\hline FIDSON & 2016 & 120,698 & 35,850 & 420,461 & $31,630,651$ \\
\hline FIDSON & 2017 & $1,060,789$ & 46,669 & 873,149 & $35,630,175$ \\
\hline FIDSON & 2018 & $-97,447$ & 42,458 & $1,049,970$ & $40,486,309$ \\
\hline PHARMA-DEKO & 2009 & $-461,497$ & 254,970 & 51,467 & 786,560 \\
\hline PHARMA-DEKO & 2010 & $-464,094$ & 145,036 & 88,664 & 822,350 \\
\hline PHARMA-DEKO & 2011 & 76,483 & 123,258 & 92,035 & 995,474 \\
\hline PHARMA-DEKO & 2012 & 740,945 & 96,467 & 67,982 & 852,749 \\
\hline PHARMA-DEKO & 2013 & $-221,789$ & 68,132 & 69,852 & 936,440 \\
\hline PHARMA-DEKO & 2014 & 101,007 & 53,396 & 244,018 & $1,032,385$ \\
\hline PHARMA-DEKO & 2015 & 659,264 & 72,340 & 311,608 & $1,205,512$ \\
\hline PHARMA-DEKO & 2016 & $-218,704$ & 100,349 & 454,522 & $1,730,265$ \\
\hline PHARMA-DEKO & 2017 & 12,607 & 95,752 & 340,394 & $1,305,615$ \\
\hline PHARMA-DEKO & 2018 & 14,326 & 92,712 & 209,590 & $1,310,513$ \\
\hline Neimeth Nig. Plc & 2009 & -455206 & 96,467 & 601,201 & 689,722 \\
\hline Neimeth Nig. Plc & 2010 & -126133 & 96,467 & 655,123 & 855,112 \\
\hline Neimeth Nig. Plc & 2011 & 113077 & 96,467 & 653,618 & 733,615 \\
\hline Neimeth Nig. Plc & 2012 & -59936 & 96,467 & 436,246 & 536,274 \\
\hline Neimeth Nig. Plc & 2013 & 130578 & 96,467 & 890,062 & 915,730 \\
\hline Neimeth Nig. Plc & 2014 & -228535 & 96,467 & 581,910 & 638,295 \\
\hline Neimeth Nig. Plc & 2015 & -335684 & 96,467 & 521,215 & 601,291 \\
\hline Neimeth Nig. Plc & 2016 & 65093 & 96,467 & 85,818 & 95,809 \\
\hline Neimeth Nig. Plc & 2017 & -411484 & 96,467 & 594,710 & 634,017 \\
\hline Neimeth Nig. Plc & 2018 & 184035 & 96,467 & 614,172 & 704,728 \\
\hline GlaxoSmithKline (GSK) Nigeria Plc & 2009 & 1701829 & 347,017 & 867,294 & 995,726 \\
\hline GlaxoSmithKline (GSK) Nigeria Plc & 2010 & 1977394 & 354,980 & $1,348,463$ & $1,481,380$ \\
\hline GlaxoSmithKline (GSK) Nigeria Plc & 2011 & 2294988 & 495,036 & $1,941,935$ & $1,935,091$ \\
\hline GlaxoSmithKline (GSK) Nigeria Plc & 2012 & 2823526 & 223,256 & $1,599,570$ & $2,059,940$ \\
\hline
\end{tabular}




\begin{tabular}{llllll}
\hline COMPANY & YEARS & PAT & EBC & RMC & CDC \\
\hline GlaxoSmithKline (GSK) Nigeria Plc & 2013 & 2919170 & 196,407 & $1,980,569$ & $2,280,585$ \\
GlaxoSmithKline (GSK) Nigeria Plc & 2014 & 1848842 & 168,139 & 980,246 & $1,530,291$ \\
GlaxoSmithKline (GSK) Nigeria Plc & 2015 & 873134 & 97,489 & 893,557 & 953,285 \\
GlaxoSmithKline (GSK) Nigeria Plc & 2016 & 2378145 & 529,026 & $1,091,037$ & $1,639,780$ \\
GlaxoSmithKline (GSK) Nigeria Plc & 2017 & 486433 & 93,481 & 219,781 & 321,750 \\
GlaxoSmithKline (GSK) Nigeria Plc & 2018 & 617624 & 174,508 & 381,670 & 490,683 \\
May \& Baker Nigeria Plc & 2009 & 232081 & 108,513 & 102,531 & 192,452 \\
May \& Baker Nigeria Plc & 2010 & 192977 & 98,060 & 98,342 & 102,391 \\
May \& Baker Nigeria Plc & 2011 & 222172 & 263,820 & 125,947 & 180,795 \\
May \& Baker Nigeria Plc & 2012 & 75943 & 61,519 & 53,562 & 62,905 \\
May \& Baker Nigeria Plc & 2013 & -103089 & 102,625 & 46,732 & 59,783 \\
May \& Baker Nigeria Plc & 2014 & 63340 & 59,473 & 53,260 & 60,620 \\
May \& Baker Nigeria Plc & 2015 & 68033 & 62,372 & 55,138 & 62,193 \\
May \& Baker Nigeria Plc & 2016 & -41094 & 50,385 & 32,945 & 39,810 \\
May \& Baker Nigeria Plc & 2017 & 336619 & 193,302 & 104,821 & 193,682 \\
May \& Baker Nigeria Plc & 2018 & 585200 & 295,879 & 218,618 & 308,791 \\
\hline
\end{tabular}

Source: Annual Report and Financial Statements of the selected pharmaceutical firms (2009-2018)

Table 5. Unit Root Test Results.

\begin{tabular}{|c|c|c|c|c|}
\hline Method & Statistic & Prob.*** & Cross-sections & Obs \\
\hline \multicolumn{5}{|c|}{ Null: Unit root (assumes common unit root process) } \\
\hline Levin, Lin \& Chu t* & -7.12776 & 0.0000 & 2 & 13 \\
\hline Breitung t-stat & -0.41153 & 0.3403 & 2 & 11 \\
\hline \multicolumn{5}{|c|}{ Null: Unit root (assumes individual unit root process) } \\
\hline Im, Pesaran and Shin W-stat & -0.81670 & 0.2070 & 2 & 13 \\
\hline ADF - Fisher Chi-square & 9.96278 & 0.0411 & 2 & 13 \\
\hline PP - Fisher Chi-square & 24.1316 & 0.0001 & 2 & 15 \\
\hline
\end{tabular}

** Probabilities for Fisher tests are computed using an asymptotic Chi -square distribution. All other tests assume asymptotic normality.

Panel unit root test: Summary

Series: $D$ (LNPAT)

Date: 12/12/19 Time: 11:12

Sample: 20092018

Exogenous variables: Individual effects, individual linear trends

User-specified lags: 1

Newey-West automatic bandwidth selection and Bartlett kernel

\begin{tabular}{|c|c|c|c|c|}
\hline Method & Statistic & Prob.** & Cross-sections & Obs \\
\hline \multicolumn{5}{|c|}{ Null: Unit root (assumes common unit root process) } \\
\hline Levin, Lin \& Chu t* & -5.08481 & 0.0000 & 3 & 21 \\
\hline Breitung t-stat & 0.12002 & 0.5478 & 3 & 18 \\
\hline \multicolumn{5}{|c|}{ Null: Unit root (assumes individual unit root process) } \\
\hline Im, Pesaran and Shin W-stat & -0.69967 & 0.2421 & 3 & 21 \\
\hline ADF - Fisher Chi-square & 12.6338 & 0.0492 & 3 & 21 \\
\hline PP - Fisher Chi-square & 24.1582 & 0.0005 & 3 & 24 \\
\hline
\end{tabular}

** Probabilities for Fisher tests are computed using an asymptotic Chi -square distribution. All other tests assume asymptotic normality.

Panel unit root test: Summary

Series: $D$ (LNEBC)

Date: 12/12/19 Time: 11:14

Sample: 20092018

Exogenous variables: Individual effects, individual linear trends

User-specified lags: 1

Newey-West automatic bandwidth selection and Bartlett kernel

Balanced observations for each test

\begin{tabular}{|c|c|c|c|c|}
\hline Method & Statistic & Prob.*** & Cross-sections & Obs \\
\hline \multicolumn{5}{|c|}{ Null: Unit root (assumes common unit root process) } \\
\hline Levin, Lin \& Chu t* & -10.1576 & 0.0000 & 5 & 35 \\
\hline
\end{tabular}




\begin{tabular}{llll}
\hline Method & Statistic & Prob.** & Cross-sections \\
\hline Breitung t-stat & 0.07300 & 0.5291 & 5 \\
Null: Unit root (assumes individual unit root process) & & & \\
Im, Pesaran and Shin W-stat & -1.14502 & 0.1261 & 5 \\
ADF - Fisher Chi-square & 23.0384 & 0.0106 & 5 \\
PP - Fisher Chi-square & 47.2031 & 0.0000 & 5 \\
\hline
\end{tabular}

** Probabilities for Fisher tests are computed using an asymptotic Chi -square distribution. All other tests assume asymptotic normality.

Panel unit root test: Summary

Series: D (LNRMC)

Date: 12/12/19 Time: 11:16

Sample: 20092018

Exogenous variables: Individual effects, individual linear trends

User-specified lags: 1

Newey-West automatic bandwidth selection and Bartlett kernel

Balanced observations for each test

\begin{tabular}{llll}
\hline Method & Statistic & Prob.** & Cross-sections \\
\hline Null: Unit root (assumes common unit root process) & & & \\
Levin, Lin \& Chu t* & -4.98539 & 0.0000 & 5 \\
Null: Unit root (assumes individual unit root process) & & & \\
ADF - Fisher Chi-square & 28.9961 & 0.0012 & 5 \\
PP - Fisher Chi-square & 73.6702 & 0.0000 & 5 \\
\hline
\end{tabular}

** Probabilities for Fisher tests are computed using an asymptotic Chi

-square distribution. All other tests assume asymptotic normality.

Panel unit root test: Summary

Series: D (LNCDC)

Date: 12/12/19 Time: 11:18

Sample: 20092018

Exogenous variables: None

User-specified lags: 1

Newey-West automatic bandwidth selection and Bartlett kernel

Balanced observations for each test

Table 6. Cointegration Test Result.

\begin{tabular}{|c|c|c|c|c|c|}
\hline \multicolumn{6}{|c|}{ Alternative hypothesis: common AR coefs. (within-dimension) } \\
\hline & & Statistic & Prob. & Statistic & Prob. \\
\hline Panel v-Statistic & & -0.902237 & 0.8165 & -1.050511 & 0.8533 \\
\hline Panel rho-Statistic & & 0.314059 & 0.6233 & 0.626877 & 0.7346 \\
\hline Panel PP-Statistic & & -5.949378 & 0.0000 & -5.778653 & 0.0000 \\
\hline Panel ADF-Statistic & & -5.771686 & 0.0000 & -4.380623 & 0.0000 \\
\hline \multicolumn{6}{|c|}{ Alternative hypothesis: individual AR coefs. (between-dimension) } \\
\hline & & Statistic & Prob. & & \\
\hline Group rho-Statistic & & 1.435739 & 0.9245 & & \\
\hline Group PP-Statistic & & -6.887059 & 0.0000 & & \\
\hline Group ADF-Statistic & & -5.259990 & 0.0000 & & \\
\hline \multicolumn{6}{|c|}{ Cross section specific results } \\
\hline \multicolumn{6}{|c|}{ Phillips-Peron results (non-parametric) } \\
\hline Cross ID & AR(1) & Variance & HAC & Bandwidth & Obs \\
\hline FIDSON & -0.483 & 0.167234 & 0.167234 & 0.00 & 6 \\
\hline PHARMA-DEKO & & Dropped from Test & & & \\
\hline Neimeth & & Dropped from Test & & & \\
\hline GlaxoSmithKline & 0.003 & 0.010582 & 0.005173 & 8.00 & 9 \\
\hline May \& Baker & -0.436 & 0.009741 & 0.005063 & 3.00 & 5 \\
\hline
\end{tabular}




\begin{tabular}{llllll}
\hline \multicolumn{2}{l}{ Augmented Dickey-Fuller results (parametric) } & & & & Max lag \\
\hline Cross ID & AR(1) & Variance & Lag & 0 & Obs \\
\hline FIDSON & -0.483 & 0.167234 & 0 & & 6 \\
PHARMA-DEKO & & Dropped from Test & & & \\
Neimeth & & Dropped from Test & & 0 & 9 \\
GlaxoSmithKline & 0.003 & 0.010582 & 0 & 0 & 5 \\
May \& Baker & -0.436 & 0.009741 & 0 & 0 \\
\hline
\end{tabular}

Pedroni Residual Cointegration Test

Series: LNPAT LNEBC LNRMC LNCDC

Date: 12/12/19 Time: 11:19

Sample: 20092018

Included observations: 50

Cross-sections included: 3 (2 dropped)

Null Hypothesis: No cointegration

Trend assumption: No deterministic trend

Automatic lag length selection based on SIC with a max lag of 0

Newey-West automatic bandwidth selection and Bartlett kernel

\section{References}

[1] Karamat, J., Shurong, T., Ahmad, N., Afridi, S., Khan, S., \& Khan, N. (2019). Developing sustainable healthcare systems in developing countries: Examining the role of barriers, enablers and drivers on knowledge management adoption. MDPI, 11 (954), 1-31. Available online at: www.mdpi.com/journal/sustainability.

[2] Kai, C. (2015). The effect of environmental performance and preference disclosure on financial performance: Empirical evidence from unbalanced panel data of heavy-pollution industries in China. Journal of Industrial Engineering and Management, 8 (1).

[3] Makori, D. M. \& Jagongo, A. (2013). Environmental accounting and firm profitability: An empirical analysis of selected firms listed in Bombay Stock Exchange, India. International Journal of Humanities and Social Science, 3 (18), 248-256.

[4] Wright, C. J. \& Noe, B. F. (2006). Theory of Environment and Planning. India: Prentice Hall.

[5] Ezejiofor, R. A., John-Akamelu, R. \& Ben-Eucharia, C. C. (2016). Effect of sustainability environmental cost accounting on financial performance of Nigerian corporate organizations. International Journal of Scientific Research and Management (IJSRM), 4 (08), 4536-4549.

[6] Manrique S. \& M. Carmen (2017). Analyzin the effect of Corporate Environmental Performance on Corporate Financial Performance in Developed and Developing Countries. Sustainability. 9. 1957.

[7] Hasan, Ş. \& Hakan, Ö. (2012). The Importance of Environmental Accounting in the Context of Sustainable Development and Within IFRS Evaluation. International Symposium on Sustainable Development, Sarajevo.

[8] Khudhair, A. A., Norwani, N. M., Ahmed, A. A. H. K. \&Aljajawy, T. M. (2019). The relationship between corporate social responsibility and financial performance of Iraqi corporations: A literature review. Journal of Modern Accounting and Auditing, 15 (1), 28-33.

[9] Niresh, J. A., \& Silva, W. H. E. (2018). The nexus between corporate social responsibility disclosure and financial performance: Evidence from the listed banks, finance and insurance companies in Sri Lanka. Accounting and Finance Research, 7 (2), 65.

[10] Etale, L. M. \&Otuya, S. (2018). Environmental responsibility reporting and financial performance of quoted oil and gas companies in Nigeria. European Journal of Business and Innovation Research, 6 (6), 23-34.

[11] Akparhuere, G. O. (2019). Environment reporting in annual reports: A comparative analysis of reporting practices of listed firms in Nigeria. Archives of Business Research, 7 (2), $183-$ 206.

[12] Obara, Ohaka and Nangih (2017). The effect of accounting for waste management expenditure on the profitability of oil and gas companies in Nigeria. International Journal of Economics, Commerce and Management, V (3), 68-81.

[13] Nyirenda, G., Ngwakwe, C. C. \&Ambe, C. M. (2013). Environmental management practices and firm performance in a South African mining firm. Managing Global Transitions, 11 (3), 243-260.

[14] Nnamani, J. N. \& Onyekwelu, U. L. (2017). Effect of sustainability accounting and reporting on financial performance of firms in Nigeria brewery sector. European Journal of Business and innovation Research, 5 (1), 1-15.

[15] Owolabi, F., Adetula, D., Taleatu, A. \&Uwuigbe, U. (2016). Assessment of sustainability reporting in Nigerian industrial goods sector, 3RD International Conference on Africa Development Issues (CU - ICADI), 383-386.

[16] Ofoegbu, G. N., Odoemelam, N. \&Okafor, R. G. (2018). Corporate board characteristics and environmental disclosure quantity: Evidence from South Africa (integrated reporting) and Nigeria (traditional reporting). Cogent Business and Management, 15, 1-27.

[17] Malarvizhi, P. \& Ranjani, M. (2016). Link between corporate environmental disclosure and firm performance. Perception or reality? Review of Integrated Business \& Economic Research, $5(3)$.

[18] Menhat, M. \& Yusuf, Y. (2018). Factors influencing the choice of performance measures for the oil and gas supply chain. iCITES, 1-9.

[19] Alawiye-Adams, A. A. \& Akumolafe, A. (2017). Environmental disclosure practices in annual reports of listed manufacturing firms in Nigeria, available at https://papers.ssrn.com/sol3/papers.cfm?abstract_id=2951272. 
[20] Zhang, K. Q. \& Chen, H. H. (2017). Environmental performance and financing decisions impact on sustainable financial development of Chinese environmental protection enterprises. Sustainability, 9, 1-14.

[21] Odera, O., Scott, A. \&Gow, J. (2016). An examination of the quality of social and environmental disclosures by Nigerian oil companies. Corporate Governance, 16 (2), 400-419.

[22] Osazefua, I. J. (2019). Operational efficiency and financial sustainability of listed manufacturing companies in Nigeria. Journal of Accounting and Taxation, 11 (1), 17-31.

[23] Dibia, N. O. \& Onwuchekwa, J. C. (2015). Determinants of environmental disclosures in Nigeria: A case study of oil and gas companies. International Journal of Finance and Accounting, 4 (3), 145-152.

[24] Okegbe, T. O. \& Ofurum, D. I. (2019). The effect of environmental management accounting and financial performance of Nigerian consumer goods firms. International Journal of Advanced Academic Research | Social and Management Sciences, 5 (1), 1-17.

[25] Shehu, U. H. (2014). Environmental costs and firm performance: evidence from quoted oil and gas companies in Nigeria.

[26] Mohammed, S. D. (2018). Mandatory social and environmental disclosure: A performance evaluation of listed Nigerian oil and gas companies pre- and post-mandatory disclosure requirements. Finance and Accounting, 6 (2), 56-68.

[27] Ndubuisi-Okolo, P. U., Anekwe, R. I. \& Attah, E. Y. (2016). Waste management and sustainable development in Nigeria: A study of Anambra State Waste Management Agency. European Journal of Business and Management, 8 (17), 132144.
[28] Nwaiwu, N. J. \& Oluka, N. O. (2018). Environmental cost disclosure and financial performance of oil and gas in Nigeria. International Journal of Advanced Academic Research | Financial Management, 4 (2), 1-23.

[29] Nazaripour, M. \& Shadi, H. (2015). Impact of debt financing and effective debt management on performance assessment in Tehran stock exchange. Mediterranean Journal of Social Sciences MCSER Publishing, Rome-Italy, 6 (6), 101-108.

[30] Agbo, B. O., Ohaegbu, O. K. \&Akubuilo, F. (2017). Effect of environmental cost on financial performance of Nigerian brewery. European Journal of Business and Management, 9 (7), 59-64.

[31] Abubakar, A. A. \&Akomolafe, A. (2017). Influence of firms attributes on environmental disclosure in listed brewery companies in Nigeria. Research Journal of Finance and Accounting, 8 (21), 31-35.

[32] Bolton, A. (2018). Climate Change and Environmental Health. Christchurch: ESR publisher.

[33] Pruss-Ustün A, Wolf J, Corvalan C, et al. 2016. Preventing Disease through Healthy Environments: A global assessment of the burden of disease from environmental risks. Geneva: World Health Organization.

[34] Royal Society of New Zealand (2017). Human Health Impacts of Climate Change for New Zealand. Wellington: Royal Society of New Zealand.

[35] World Health Organization and Healthcare Without Harm (2009). Healthy Hospitals, Healthy Planet, Healthy People: Addressing climate change in healthcare settings. URL: www.who.int/globalchange/publications/healthcare settings/e n. 